\title{
MICROSATELLITE ANALYSIS OF GOLDEN GREY MULLET Chelon auratus (RisSo, 1810) IN THE FEREYDOON - KENAR AND RAMSAR COASTS (SOUTH CASPIAN SEA, IRAN)
}

\author{
Mohammad Behrouz ${ }^{1}$, Mehrnoush Norouzi $^{1 *}$, Mohammad Hadi Samiei ${ }^{1}$, Pouria \\ Heshmatzad $^{2}$
}

'Department of Marine Biology and Fisheries Sciences, Tonekabon Branch, Islamic Azad University, Tonekabon, Iran

${ }^{2}$ Young Researchers and Elite Clup, Kermanshah Branch, Islamic Azad University, Kermanshah, Iran.

*Corresponding Author, Email: mnoroozi@toniau.ac.ir

\section{ARTICLE INFO}

Received: 15 December 2016

Received in revised form: 24 October 2017

Accepted: 11 November 2017

Available online: 21 November 2017
Keywords:

Chelon auratus

Population genetic

Microsatellite

Caspian Sea

\begin{abstract}
Genetic structure of golden grey mullet Chelon auratus investigated in the Fereydoon-Kenar and Ramsar coasts (south Caspian Sea, Iran), using 6 microsatellite markers designed for gray mullet (Mugil cephalus) and hand mullet (Liza haematocheila). A total of 60 samples of adult $C$. auratus were collected from these regions. All primer sets as polymorphic loci were used to analyze genetic variation. Analyses revealed that average of alleles $(\mathrm{Na})$ per locus was 6.2 (range 3 to 9 alleles). All sampled regions contained private alleles. The average estimates of inbreeding coefficient (Fis) values of 6 microsatellites were positive. The average observed and expected heterozygosity was 0.394 and 0.743 , respectively. Deviations from HardyWeinberg equilibrium were in all cases $(\mathrm{P}<0.001)$. F-statistics $(\mathrm{Fst})$ and gene flow $(\mathrm{Nm})$ estimates in allele frequencies were 0.078 and 2.9, respectively. Fst estimates in AMOVA indicated significant genetic differentiation among regions $(P<0.01)$. Genetic distance was 0.679 indicating that the genetic difference among the studied populations is pronounced. The data generated in this study provides genetic variation and differentiation in populations of $C$. auratus in the southern Caspian Sea.
\end{abstract}

How to Cite

Behrouz, M., Norouzi, M., Samiei, M. H., Heshmatzad, P. (2018): Microsatellite analysis of golden grey mullet Chelon auratus (Risso, 1810) in the Fereydoon-Kenar and Ramsar coasts (south Caspian Sea, Iran). Croatian Journal of Fisheries, 76, 35-40. DOI: 10.2478/cjf-2018-0004.

\section{INTRODUCTION}

Golden grey mullet Chelon auratus (Risso, 1810) is a typical marine schooling fish. It was introduced into the Caspian from the Black Sea (targeted acclimatization) and spread widely within the Caspian Sea, except for the estuarine sea areas. Golden grey mullet is found in the southern part of the sea throughout the year; in the Middle Caspian, it appears in spring and migrates back to the south in autumn. It is rarely caught in the northern part of the sea, except in the Mangyshlak area. In early March, following the rise in water temperature, it starts migration from the southern feeding grounds. In April, it appears in the Middle Caspian. During migration, it feeds intensively, preferring shallow coastal 
areas (Velikova et al., 2012). The $C$. auratusis a euryhaline fish, sensitive to a decrease in water temperature. The age of reproductive maturity is 3-4 years. Spawning takes place in the open sea, at great depths (400-500 m) and upon available aquatic vegetation. The species winters in the southern part of the Caspian. The fish is concentrated mostly in the sectors with rich marine vegetation and in areas with muddy bottoms. During the south-east winds, it moves off the shoreline notably and its concentration reduces. During the north-east winds and in still weather, the density of fish in the coastal zone increases significantly. C. auratus is a valuable commercial fish. The second mullet species introduced from the Black Sea to the Caspian is Liza saliens furcata Popov, 1930. The two Caspian mullet species are not separated (itemized) in fishery statistics; however, golden grey mullet prevails (up to 1.5 thousand tons) in the total mullet catches (Velikova et al., 2012).

Microsatellites analysis represents a very good method for individual identification and also allows the evaluation of intra-specific genetic diversity. This technique provides the ability to characterize genetic variations in sturgeon populations from aquaculture (Georgescu et al., 2014). Microsatellites are frequent in stellate sturgeon genome and can easily be amplified with PCR because microsatellite markers show high levels of allele polymorphism. Therefore, offer the basis for a successful analysis in a wide range of fundamental and applied sectors of fisheries and aquaculture (Sekar et al., 2009).

So far, few microsatellite studies on genetic diversity, population genetic structure and demographic history of the family Mugilidae have been carried out (Turan et al., 2011; Xu et al., 2009; Miggiano et al., 2005; Xu et al., 2010; Erguden et al., 2010; Ghodsi, Shabni and Shabanpour, 2011). So, the objectives of the present study are to investigate the genetic structure of $C$. auratus and test the hypothesis that C. auratus has an identical population in different regions of the South Caspian Sea (Mazandaran province).

\section{MATERIALS AND METHODS}

\section{Sample collection and DNA isolation}

The fishes were caught from two different regions, including 30 samples from Fereydoon-Kenar and 30 samples from Ramsar coasts (south Caspian Sea, Iran) (Fig. 1). These two areas are the main catchment areas of Chelon auratus. Fin tissue samples were prepared from 60 fishes at each location and preserved in 95\% ethanol, and stored at room temperature.

\section{DNA extraction microsatellites data set}

Genomic DNA was extracted from fin tissue using a high pure PCR Template preparation kit (Roach, Germany) according to the manufacturer's instructions. The quality and concentration of DNA were assessed by $1 \%$ agarose gel electrophoresis and spectrophotometry (CECIL model CE2040), and then stored at $-20^{\circ} \mathrm{C}$ until use.
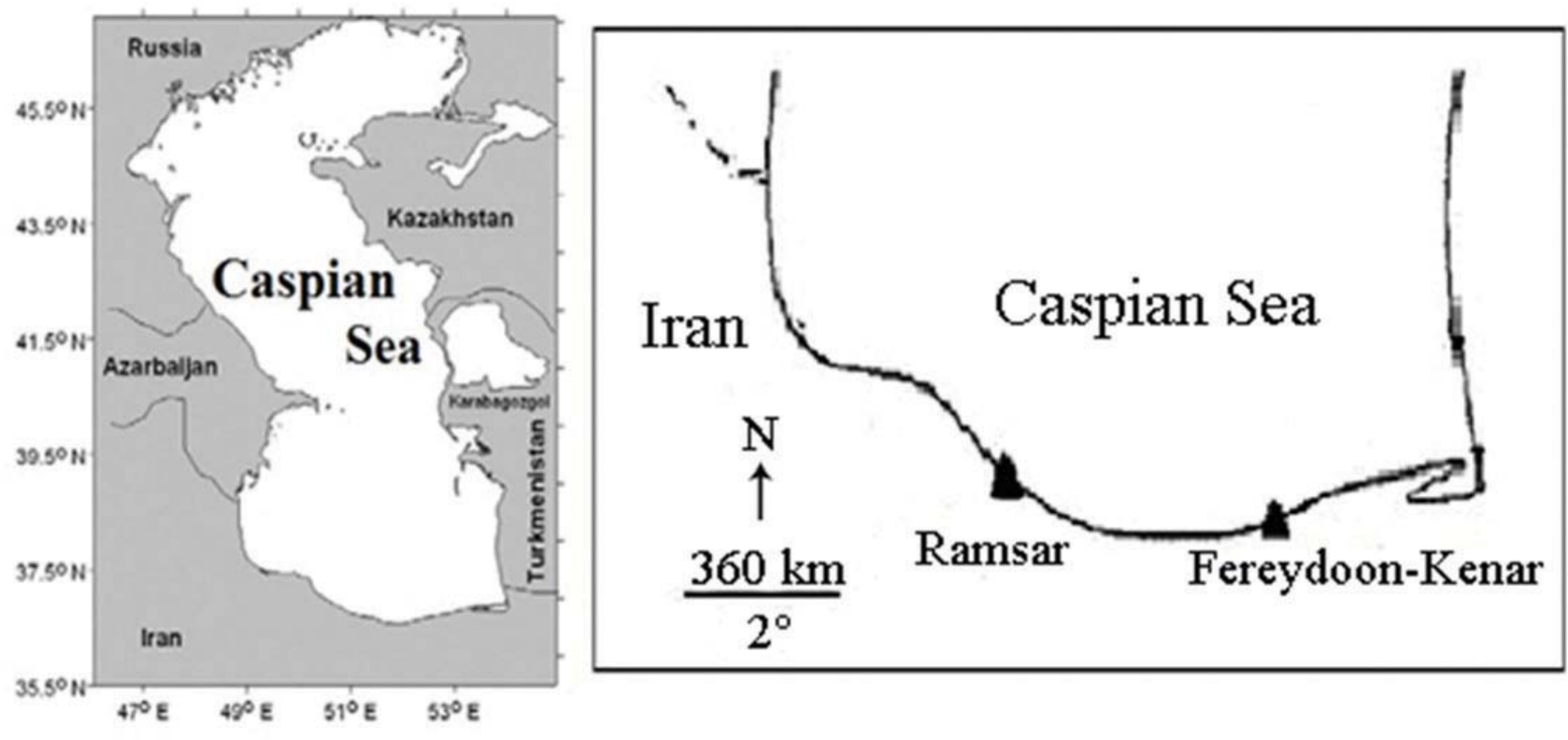

Fig 1. Map showing sampling locations of populations of main catchment areas of C. auratus: Fereydoon-Kenar and Ramsar coasts. 


\section{PCR profiles and primer sequences}

The nuclear DNA was amplified using 6 microsatellite primers designed for $M$. cephalus Muce-55, 37 (Xu et al., 2010) and Liza haematocheila Muso10, 16, 19, 22 (Xu et al., 2009). The nuclear DNA was amplified using 6 microsatellite primers designed for $M$. cephalus Muce-55, 37 (Xu et al., 2010) and Liza haematocheila Muso10, 16, 19, 22 (Xu et al., 2009). For all primer sets, amplification was performed in a reaction volume of $25 \mu \mathrm{L}$ containing $0.2 \mathrm{mM}$ of dNTPs, $1 \mu \mathrm{L}$ each primer, $100 \mathrm{ng}$ of template DNA; 0.3 units of HotStarTaq $^{\text {TM }}$ DNA polymerase; 1x HotStarTaq $^{\text {TM }}$ PCR buffer and $1.5 \mathrm{mM} \mathrm{MgCl}$. Microsatellites were amplified (see Table 1 for specific annealing temperatures) using a Eppendorf thermocycler (Mastercycler ep gradient, 96 plus, Eppendorf, Germany). An initial denaturing step of 10 minutes at $95^{\circ} \mathrm{C}$ was followed by amplification for 30 cycles with the following conditions: 30 seconds at $94-95^{\circ} \mathrm{C}$, $25-40$ seconds at $47-61.256^{\circ} \mathrm{C}$ and $45-120$ seconds at $72^{\circ} \mathrm{C}$ (Table 1). PCR products were electrophoresed on $10 \%$ polyacrylamide gels (29:1 acrylamide: bis-acrylamide; $1 \mathrm{X}$ TBE buffer) and followed by silver-staining. Gels were run at $40 \mathrm{~mA}$ for $14 \mathrm{~h}$. Alleles were sized using Uvitec software, and each gel contained an allelic ladder (100 bp) to assist with consistent scoring of alleles.

\section{Data analysis}

Allelic frequencies observed and expected heterozygosities (Ho and He), genetic distance (Nei, 1972), genetic identity, Fst and Rst value, Nm, Hardy-Weinberg (HW) tests of equilibrium and AMOVA were computed in GeanAlex 6.0 software (Peakall and Smouse, 2006). AMOVA calculations and allelic richness (AR) were performed on Arlequin 3.5 Excoffier and Lischer (2010), using 10,000 permutations in each case. BOTTLENECK 1.2.02 (Cornuet and Luikart, 1996) was used to detect recent effective population size reduction (to assess the impact of population decline), using data from the microsatellites under the more suitable twophased model (TPM).

\section{RESULTS}

All primer set information for 6 microsatellite loci for $C$. auratus has been given in Table 1 (Locus, GenBank No, Primer sequences, Repeat motif, Size range (bp), $\mathrm{Tm}^{\mathrm{C}}$ ).

A total of 53 alleles were identified in 60 individuals, 38 alleles in Fereydoon-Kenar and 37 alleles in Ramsar, with frequencies $>0.05$ in all samples. All the populations sampled contained private alleles at a significant level $(\mathrm{P}<0.05)$. In total, 5 alleles were found: 2 private alleles in Fereydoon-Kenar and 3 private alleles in Ramsar, none of which were found in other sites. Muso22 showed the maximum variability ranging in frequency from 0.067 to
0.567 . Allele sizes ranged from 116 to $350 \mathrm{bp}$. The average number of alleles found per site was 6.2 (Table 1), and the number of alleles in Muso10 ranged from 4 to $6\left(A_{R}=8\right)$, in Muso16 from 3 to $7\left(A_{R}=6\right)$, in Muso19 from 9 to 9 $\left(A_{R}=8\right)$, in Muso22 from 9 to $9\left(A_{R}=11\right)$, in Muce-37 from 5

Table 1. Numbers of alleles observed within 2 sampling sites, using 6 sets of microsatellite primers

\begin{tabular}{|c|c|c|c|c|c|}
\hline & & & gions & & \\
\hline Loci & & Ramsar & $\begin{array}{l}\text { Fereydoon- } \\
\text { Kenar }\end{array}$ & $F_{\text {is }}$ & protocol \\
\hline Мus -10 & $\mathrm{Na}$ & 6 & 4 & (1) & $510 \mathrm{C}^{130}$ \\
\hline iviuso-10 & $\mathrm{Ne}$ & 4.489 & 2.473 & 0.075 & $34 \mathrm{C}$ \\
\hline Мusn-16 & $\mathrm{Na}$ & 3 & 7 & 0565 & $56^{\circ} \mathrm{C} / 30$ \\
\hline & $\mathrm{Ne}$ & 2.936 & 4.945 & & \\
\hline Muco 10 & $\mathrm{Na}$ & 9 & 9 & 0 & \\
\hline IVIuso-19 & $\mathrm{Ne}$ & 5.167 & 7.258 & 0.040 & \\
\hline 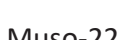 & $\mathrm{Na}$ & 5 & 5 & 1 & $51^{\circ} \mathrm{C} / 40$ \\
\hline IVIUSO-LZ & $\mathrm{Ne}$ & 2.679 & 4.206 & 1 & $51^{\circ} \mathrm{C} /$ \\
\hline Muce-27 & $\mathrm{Na}$ & 9 & 5 & 0194 & $51{ }^{\circ} \mathrm{C} / 25$ \\
\hline ול & $\mathrm{Ne}$ & 6.691 & 4.327 & דנג.ט & ( \\
\hline Muce-55 & $\mathrm{Na}$ & 5 & 8 & 0.009 & $47^{\circ} \mathrm{C} / 40$ \\
\hline & $\mathrm{Ne}$ & 3.093 & 3.797 & & \\
\hline Avarzos & $\mathrm{Na}$ & 6.167 & 6.333 & 0182 & \\
\hline Averdge & $\mathrm{Ne}$ & 4.177 & 4.501 & 0.483 & - \\
\hline
\end{tabular}

Number of studied samples ( $n$ ), number of alleles ( $\mathrm{Na}$ ), effective allele $(\mathrm{Ne})$ at 6 loci in two sampling sites

Table 2. . Numbers of alleles observed within 2 sampling sites, using 6 sets of microsatellite primers

\begin{tabular}{|c|c|c|c|c|}
\hline \multirow[t]{2}{*}{ Loci } & & \multicolumn{2}{|c|}{ Regions } & \multirow[b]{2}{*}{$\begin{array}{c}\text { Actualsize } \\
\text { (bp) }\end{array}$} \\
\hline & & Ramsar & $\begin{array}{l}\text { Fereydoon- } \\
\text { Kenar }\end{array}$ & \\
\hline \multirow{2}{*}{ Muso-10 } & Ho & 0.167 & 0 & \\
\hline & $\mathrm{He}$ & $* * * / 0.777$ & $* * * / 0.896$ & $350-312$ \\
\hline \multirow{2}{*}{ Muso-16 } & Ho & 0.167 & 0.467 & \\
\hline & $\mathrm{He}$ & $* * * / 0.659$ & $* * * / 0.798$ & $350-258$ \\
\hline \multirow{2}{*}{ Muso-19 } & Ho & 0.267 & 0.333 & \\
\hline & $\mathrm{He}$ & $* * * / 0.807$ & $* * * / 0.862$ & $166-202$ \\
\hline \multirow{2}{*}{ Muso-22 } & Ho & 0 & 0 & \\
\hline & $\mathrm{He}$ & $* * * / 0.627$ & $* * * / 0.762$ & $182-192$ \\
\hline \multirow{2}{*}{ Muce-37 } & Ho & 1 & 0.933 & \\
\hline & $\mathrm{He}$ & $* * * / 0.851$ & $* * * / 0.769$ & $192-232$ \\
\hline \multirow{2}{*}{ Muce-55 } & Ho & 0.700 & 0.700 & \\
\hline & $\mathrm{He}$ & $* * * / 0.737$ & $* * / 0.677$ & $116-152$ \\
\hline \multirow{2}{*}{ Average } & Ho & 0.383 & 0.406 & \\
\hline & $\mathrm{He}$ & 0.733 & 0.754 & \\
\hline
\end{tabular}

Observed $(\mathrm{Ho})$ and expected $(\mathrm{He})$ heterozygosities. Loci in accordance with $\mathrm{H}-\mathrm{W}$ equilibrium ${ }^{*} \mathrm{P}<0.01$; ${ }^{* *} \mathrm{P}<0.001$ 
to $9\left(A_{R}=9\right)$, in Muce-55 from 8 to $5\left(A_{R}=8\right)$. The observed and expected heterozygosity averaged 0.349 and 0.743 , respectively; the observed heterozygosity ranged from 0.383 in Ramsar to 0.406 in Fereydoon-Kenar (Table 2). The Muce-37 locus had the highest level of heterozygosity, and lower heterozygosities were consistently observed in most samples screened, which may be due to the presence of null alleles or small sample sizes. Bottleneck analysis of golden mullet was 0.04121 in Fereydoon-Kenar and 0.04014 in Ramsar.

Estimates of inbreeding coefficient or Fis values were positive and between Muce-37, 0.194; Muce-55, 0.009; Muso-16, 0.565; Muso-19, 0.640; Muso-22, 1; Muso-10, 0.879 (mean Fis $=0.483$; Table 1 ), and positive Fis values a relative dearth of heterozygotes (may be due to homozygotes). However, Muce-37 had lower Fis and higher heterozygosity than all loci in the populations assayed. Departures from HardyWeinberg equilibrium were significant $(\mathrm{P}<0.01)$ (Table 2$)$.

$\mathrm{Nm}$ and Fst via frequency ranged from 1.342 to 5.807 and from 0.041 to 0.157 , with an average of 3.679 and 0.078 , respectively. In practice, Fst is rarely higher than 0.5 and often very much lower. Fst, Rst and gene flow, as analyzed with AMOVA, showed a significant genetic differentiation among sites $(P<0.01)$, which suggested that the populations diverged from each other. The genetic distance and genetic identity computed by Nei (1972) between populations was 0.679 and 0.507 , respectively.

\section{DISCUSSION}

The results of the study on $C$. auratus show that the obtained allelic average in this study (9.5) is lower than the declared range $(19.9 \pm 6.6)$ for saltwater fish (DeWoody and Avise, 2000). Also, in this study some alleles have been observed with low frequency. This may be due to overfishing of this species in recent years. In previous years, due to overfishing of mullet, whose average weight was only 210 $\mathrm{g}$, its resources have been damaged severely. Since golden grey mullet is not indigenous to the Caspian Sea, it is likely that the small founder population which first came to the Caspian Sea from the Black Sea is the cause of reduction in allelic variation. The results of this study confirm reduction in allelic variation because many alleles with low frequency are the sign of genetic bottleneck or the result of inbreeding. The average inbreeding coefficient (Fis), which is positive for these two regions, also supports this idea.

The average heterozygosity observed in this study $(0.394 \pm 0.1)$ is lower than the declared amount for marine water fish $(0.77 \pm 0.22)$ (DeWoody and Avise, 2000). In both sampling regions there have been places in which the observed heterozygosity was lower than the expected amount. However, the observed reduced heterozygosity compared to expectable heterozygosity, reduction in allelic variation and also existence of alleles with low frequency can be due to reasons like overfishing and environmental causes like pollutants which reduce the natural breeding of this fish.

It seems $C$. auratus stock in the Caspian Sea is in a critical condition and is suffering more damage every year. Recently, unfavorable hydrological conditions related to climate change have had a negative impact on the sustainability of exploitable yield of $C$. auratus; the thermal structure of the upper layers of the sea has been detrimental to the species, and there has also been poor vertical mixing of the surface and deeper waters (Velikova et al., 2012).

Reduction in genetic variation increases the possibility of becoming ill and other selective factors, and as a result it decreases the size of population (Shen et al., 2004). Since in this study the average inbreeding coefficient was positive, it is possible that the first parents were selected from one or two places near to each other in the Black Sea or genetic variation of this species is low in the Black Sea, and it may also be related to sampling from Admixture of stocks due to specific feeding grounds or nursery areas for reproduction - sufficient information on location of the harvest is not available (Ghodsi, Shabni and Shabanpour, 2011).

Considering Hardy-Weinberg equilibrium, all places in every location were out of equilibrium $(p<0.001)$. The cause of deviation from equilibrium was sample mixing, population combination and sampling error (since the populations were small and samples were low in number). Fst based on allelic frequency was 0.078 which shows average genetic differentiation (Balloux and Lugon-Moulin, 2002). Genetic flow was calculated to be 2.9. Fst and Rst via AMOVA for codominant data in all sampling sites were significant $(\mathrm{P} \leq 0.01)$. So the populations are separated from each other, suggesting that two populations are genetically differentiated and do not represent a single panmictic population. High capacity of dispersion, which is probably due to lack of physical or ecological barriers in the south coast of the Caspian Sea, leads to high contact in subpopulations when they migrate and this is the reason of the average population structure for this species. Shaklee et al. (1982) and Thorpe and Sole-Cava (1994) showed that the Nei (1972) genetic distance for separation of populations is said to be 0.3 in average (from 0.03 to 0.61 ), which is compatible with the observed genetic distance and confirms genetic differentiation among observed populations.

\section{CONCLUSIONS}

This study shows the preliminary results and reasons for the existence of different populations of $C$. auratus in the two regions of Fereydoon-Kenar and Ramsar coasts. The existence of private alleles and significant Fst and Rst confirm different populations in the two regions. The losses of genetic diversity may increase with bottlenecking for this species in the Caspian Sea. The small founder 
population which first came to the Caspian Sea, overfishing and environmental pollution of the sea are the causes of reduction in population size which leads to reduction in allelic variation of the fish. Also, inbreeding is the reason of allelic variation reduction in every sampling location. It is possible that the members of the same family were sampled or it is because of low genetic variation in mullet fries that first came from the Black Sea into the Caspian Sea. Private alleles, difference in frequency of dominant alleles in every sampling location and the index of significant differentiation show that different populations exist in the south of the Caspian Sea, the coast of Mazandaran.

\section{ACKNOWLEDGEMENTS}

The authors thank Islamic Azad University Tonekabon Branch for the financial support.

\section{Sažetak}

\section{ANALIZA MIKROSATELITA CIPLA ZLATARA, Chelon auratus (Risso, 1810) NA OBALAMA FEREYDOON-KENAR I RAMSAR (JUG KASPIJSKOG JEZERA, IRAN)}

Genetska struktura cipla zlatara, Liza aurata, istražena na obalama Fereydoon-Kenara i Ramsara (jug Kaspijskog jezera, Iran) pomoću 6 mikrosatelitskih markera dizajniranih za cipla bataša (Mugil cephalus) i Liza haematocheila. Ukupno je sakupljeno 60 odraslih primjeraka $L$. aurata iz tih regija. Sve početnice polimofnih lokusa su upotrijebljene za analizu genetske varijacije. Analiza je otkrila kako je prosječan broj alela ( $\mathrm{Na}$ ) po lokusu 6,2 (raspon je 3 do 9 alela). Sve regije uzorka sadržavale su privatne alele. Prosječne procjene vrijednosti koeficijenta parenja u bliskom srodstvu (Fis) na 6 mikrosatelita su pozitivne. Prosječna promatrana i očekivana heterozigotnost je 0,394 i 0,743. Devijacije od Hardy-Weinbergovog modela ravnoteže zabilježene su u svim slučajevima $(P<0,001)$. Procjene $F$ statistike $(F s t)$ i genskog toka $(\mathrm{Nm})$ bile su 0,078 i 2,9. Fst procjene u AMOVA ukazuju na značajnu gensku diferencijaciju između regija $(P<0,01)$. Genetska udaljenost je 0,679, što upućuje na izraženu genetsku diferencijaciju između proučavanih populacija. Podaci proizašli iz ove studije pružaju genetsku varijaciju i genetsku diferencijaciju u populacijama poput $C$. auratus na jugu Kaspijskog jezera.

Ključne riječi: Chelon auratus, populacijska genetika, mikrosateliti, Kaspijsko jezero

\section{REFERENCES}

Balloux, F., Lugon-Moulin, N. (2002): The estimation of population differentiation with microsatellite markers.
Molecular ecology, 11, 2, 155-165.

Cornuet, J.M., Luikart, G. (1996): Description and power analysis of two tests for detecting recent population bottlenecks from allele frequency data. Genetics, 144,4, 2001-2014.

DeWoody, J.A., Avise, J.C. (2000): Microsatellite variation in marine, freshwater and anadromous fishes compared with other animals. Journal of Fish Biology, 56, 3, 461473.

Erguden, D., Gurlek, M., Yaglioglu, D., Turan, C. (2010): Genetic identification and taxonomic relationship of Mediterranean mullet species based on mitochondrial $16 \mathrm{~S}$ rDNA sequence data. Journal of Animal and Veterinary Advances, 9, 2, 336-341.

Excoffier, L., Lischer, H.E.L. (2010): Arlequin suite ver 3.5: a new series of programs to perform population genetics analyses under Linux and Windows. Molecular ecology resources, 10, 3, 564-567.

Georgescu, S.E., Burcea, A., Florescu, I., Popa, O.G., Dudu, A., Costache, M. (2014): Microsatellite variation in Russian sturgeon (Acipenser gueldenstaedtii) from aquaculture. Scientific Papers Animal Science and Biotechnologies, 47, 1, 73-76.

Ghodsi, Z., Shabni, A., Shabanpour, B. (2011): Genetic diversity of Liza aurata (Risso, 1810) in the coastal regions of Golstan province, using microsatellite marker. Taxonomy and Biosystematics, 3, 6, 35-45.

Miggiano, E., Lyons, R.E., Li, Y., Dierens, L.M., Crosetti, D., Sola, L. (2005): Isolation and characterization of microsatellite loci in the striped mullet, Mugil cephalus. Molecular Ecology Notes, 5, 2, 323-326.

Nei, M. (1972): Genetic Distance between Populations. The American Naturalist, 106, 949, 283-292.

Peakall, R., Smouse, P. e. (2006): genalex 6: genetic analysis in Excel. Population genetic software for teaching and research. Molecular Ecology Notes, 6, 1, 288-295.

Sekar, M., Suresh, E., Kumar, N.S., Nayak, S.K., Balakrishna, C., Reaction, P.C. (2009): Microsatellite DNA markers, a fisheries perspective Part 1: The nature of microsatellites Aquaculture Asia, 14, 2, 27-29.

Shaklee, J.B., Tamaru, C.S., Waples, R.S. (1982): Speciation and evolution of marine fishes studied by the electrophoretic analysis of proteins. Pacific Science, 36, 2, 141-157.

Shen, X.Y., Gong, Q.L., Lei, J.L., Kong, J., Zhai, J.M., Li, B. (2004): Population genetic structure analysis of the imported turbot seedlings Scophthalmus maximus L. using RAPD and Microsatellite technique. Oceanologia et limnologia sinica, 35, 4, 340-349.

Thorpe, J.P., Sole-Cava, A.M. (1994): The use of allozyme electrophoresis in invertebrate systematics. Zoologica Scripta, 23, 1, 3-18.

Turan, C., Gurlek, M., Erguden, D., Yaglioglu, D., Ozturk, B. (2011): Systematic status of nine mullet species (Mugilidae) in the Mediterranean Sea. Turkish Journal of Fisher- 
ies and Aquatic Sciences, 11, 2, 315-321.

Velikova, V.N., Shaudanov, A.K., Gasimov, A., Korshenko, A., Abdoli, A., Morozov, B., Katunin, D.N., Mammadov, E., Bokova, E.B., Emadi, H. (2012) :Review of the environment and bioresources in the Caspian Sea ecosystem 2000-2010. CaspEco Report. 423.

Xu, G., Shao, C., Liao, X., Tian, Y., Chen, S. (2009): Isolation and charaterization of polymorphic microsatellite loci from so-iuy mullet (Mugil soiuy Basilewsky, 1855). Conservation Genetics, 10, 3, 653-655.

Xu, T.J., Sun, D.Q., Shi, G., Wang, R.X. (2010): Development and characterization of polymorphic microsatellite markers in the gray mullet (Mugil cephalus). Genetics and Molecular Research, 9, 3, 1791-1795. 